\title{
IMPLEMENTASI PEMURIDAN KONTEKSTUAL
}

BAGI MAHASISWA TEOLOGI KRISTEN DALAM PELAYANAN DI GEREJA

Oleh :

\section{KRISTIANI TIMANG \\ 1020175382 \\ C/PAK}

\section{Gmail: timangkristiani695@gmail.com}

\section{A. Abstrack}

Ada banyak gereja yang telah merasakan manfaat dari proses pemuridan. Salah satunya manfaat yang dapat dilihat adalah bahwa seseorang yang telah mengikuti proeses pemuridan mengalami pertumbuhan dalam kehidupan rohaninya menuju kepada kedewasaan rohani. Dengan demikian, kita dituntut untuk lebih aktif dalam pelayanan. Ketika kita menekuni pelayanan dalam gereja akan timbul kecintaan akan Firman Allah serta rela dan mau terlibat dalam pelayanan di dalam jemaat.

\section{B. Pendahuluan}

Kampus merupakan sebuah wadah pembinaan yang sangat efektif, dan efisien mengingat homogenitas dalam level yang sama, mobilitas yang tertinggi, semangat muda yang berapi-api serta interaksi yang kuat diantara mereka. mahasiswa yang hadir dalam kampus adalah calon pemimpin, dan jika calon pemimpin di bina dengan baik maka akan menjadi memimpin yang mampu dalam bidang yang ia tekuni nantinya. Melihat dari sini, pembinaan dan pengelolaan pelayanan mahasiswa dinilai sangat strategis dalam visi pelayanan mahasiswa.

Istilah gereja berasal dari bahasa Yunani Kuno, ekklesia (bahasa Latin: ecclesia) artinya "jemaat gereja", dan akhiran logia, yang berarti "perkataan" $<$ "pengetahuan", atau "logika". Gereja adalah sekumpulan orang percaya yang berkumpul bersama untuk beribadah di dalam nama Yesus Kristus dengan tugas untuk membawa orang yang masih berada dalam gelap kepada terang Tuhan. Sebagaimana pembelaan rasul Paulus yang dengan berani menyatakan bahwa semua orang percaya memiliki tugas untuk menjadi pelayan dan saksi iman dan membawa keluar orang dari kuaa kegelapan kepada terang Tuhan dan dikuduskan (Kisah Para Rasul 26:16-18). Pertanyaannya adalah apakah gereja-gereja Kristen pada masa kini 
masih selaras dengan spirit yang dimiliki oleh para rasul dalam Perjanjian Baru dimana mereka berjuang bersama untuk membangun Kerajaan Allah. ${ }^{1}$ Boland juga mengatakan bahwa banyak gereja yang merayakan ulang tahun "gerejanya" masingmasing sebagai ekspresi eklusifitas yang sangat berbeda dengan gerakan para rasul. Mereka tidak memusingkan gereja apa atau mana yang terpenting adalah jiwa-jiwa yang terselamatkan dan terpelihara dengan baik. ${ }^{2}$ Gereja mengembangkan proses pemuridan untuk menolong, mengarahkan dan menangani hasil-hasil dari pekabaran Injil dan memantapkan orang-orang baru percaya tersebut ke dalam persekutuan. ${ }^{3}$ Gereja hadir bagi mereka yang mau mengenal Yesus sebagai Sang Juruselamat.

\section{Tujuan}

Untuk mengetahui IMPLEMENTASI PEMURIDAN KONTEKSTUAL

\section{SEBAGAI KONSELING BAGI MAHASISWA IAKN TORAJA YANG AKTIF DALAM PELAYANAN DI GEREJA.}

\section{Manfaat}

Memberikan sumbangan pengetahuan dalam bidang pelayanan gereja bagi mahasiswa.

\section{E. Pembahasaan}

Gereja mengemban tugas Allah yang disebut sebagai Missio Dei. Allah mengkehendaki bahwa kerajaan Allah harus dinyatakan di bumi ini. Persoalan kerajaan Allah ini mengandung tiga pandangan yang berbeda. Menurut Kees De Jong, pandangan pertama menganut visi tradisional yang melihat bahwa gereja adalah kerajaan Allah dalam sejarah. Pendapat kedua mengatakan bahwa gereja bukan kerajaan Allah melainkan gereja adalah awal mula dan hasil pertama dari Kerajaan Allah yang akan disempurnakan oleh Allah sendiri di masa depan. Oleh sebab itu, gereja harus terus membangun keadilan, persaudaraan dan kebebasan dalam sejarah. ${ }^{4}$ Dari pendapat diatas kita diminta untuk berpikir kritis, bukankah gereja sebagai tubuh Kristus kurang dalam memahami konsep bermisi. Realita dari konsep Missio Dei seharusnya merangkul semua umat Tuhan yang percaya dan tidak percaya, atau

\footnotetext{
${ }^{1}$ Jurnal Fidel, Vol.2, No.1, June 2019

2 Boland, BJ., Van Niftrik, Dogmatika Masa Kini (Jakarta: BPK. Gunung Mulia, 2015), 352

${ }^{3}$ Raymond C. Ortlund, Filsafat Pelayanan Berdasarkan Alkitab, terj., (Surabaya: Yakin, 2000$) 67$.

4 Kees De Jong, "Misiologi dari Perspektif Teologi Kontekstual" Gema Teologi, - sac.ukdw.acid. 2007;56
} 
apapun agamanya. Gereja atau orang-orang percaya harus kembali kepada jati dirinya sebagai kumpulan orang-orang yang dipersatukan oleh Tuhan Yesus Kristus.

Gereja yang berfokus.. (Hery Susanto)

"Memang tidak salah bagi gereja untuk menolong orang-orang yang berkekurangan dan tidak berdaya. Gereja harus melakukan hal itu, tetapi tidak membatasi gereja hanya pada pekerjaan-pekerjaan amal dan menyebutnya sebagai sebuah pelayanan. Gereja Tuhan melebihi dari sekedar kegiatan amal, proyek pendidikan, misi darurat, dan sebagainya...

Gereja Tuhan lebih besar dari semua itu"5

Gereja berfokuskan pada satu arah yaitu Yesus Kristus. Apapun masalah yang terajdi dalam kehidupan mereka harus tetap bersama dalam satu pemerintah yaitu Yesus Kristus sendiri. Sebagai bagian dari gambar dan rupa Allah tentunya kita berani mengalahkan segala masalah yang ada.

Yesus memulai pelayanannya dengan proses rekrutmen orang-orang biasa untuk menjadi muridNya. Proses rekrutmen tersebut dilanjutkan kepada proses pemuridan. Kesinambungan proses rekrutmen dan pemuridan Yesus dapat dilihat dari 2 perikop Alkitab yaitu, Lukas 5:1-11 dan Yohanes 21:1-23. ${ }^{6}$

Implementasi amanat agung secara internal harus digarap oleh gereja secara institusional dan sistematis sehingga gereja hadir di suatu tempat tidak hanya untuk hiburan atau memberi semangat kepada orang-orang yang terluka atau membangun kepercayaan diri atau memberi fasilitas dalam menjalin persahabatan, tetapi untuk memuji Tuhan. ${ }^{7}$ Kata "memuji Tuhan" tidak boleh diartikan hanya sebagai ritual keagamaan yang dilakukan setiap ibadah minggu. Prinsip teosentris merupakan pondasi dalam seluruh sistem kehidupan untuk memuji Tuhan secara benar. Dalam kondisi seperti itu gereja memahami kehidupan beriman dan iman yang antropsentris. $^{8}$

Pemuridan gerejawi bertujuan untuk mendidik jemaat dalam melakukan segala sesuatu yang diperintahkan Tuhan. Fokus mengajarkan murid-murid untuk melakukan perintah Tuhan sebagai bagian akhir dan awal dimulainya kembali memennuhi Amanat Agung. Jalan yang yang ditempuh adalah "mengajak dan megikutertakan"

\footnotetext{
${ }^{5}$ William Vun. 2010. Who is Building Whose Church? (Jakarta: Nafiri Gabriel, 2010),36

${ }^{6}$ Jurnal Gamaliel: Teologi Praktika, Vol 1, No 1, Maret 2019

${ }^{7}$ Philip Yancey, Gereja: Mengapa Dirisaukan, terj., (Bandung: Cipta Olah Pustaka, 2001)30.

${ }^{8}$ Hans Maris, Gerakan Karismatik dan Gereja Kita, terj., (Surabaya: Momentum, 2004), 29.
} 
murid-murid untuk menghadiri suatu kebaktian secara teratur. ${ }^{9}$ Tuhan mengutus para murid untuk para murid untuk pergi ke segala suku bangsa di seluruh dunia untuk menjadikan mereka muridNya. Pemuridan yang sejati adalah komitmen yang utuh, tuntas kepada Kristus Tuhan. Komitmen adalah kualitas vital dari pemuridan. Nila kita komit, kita dapat mengubah dunia. ${ }^{10}$

Pelayanan mahasiswa Kristen ada di hampir setiap perguruan tinggi di Indonesia, termasuk pada perguruan tinggi negeri. Pelayanan mahasiswa Kristen yang dimaksudkan adalah persekutuan bersama-sama dengan rekan kampus atau bersama jemaat di suatu gereja. Pelayanan mahasiswa Kristen menonjol bukan saja karena jumlah dan jenis kegiatannya, tetapi juga unik dalam kegiatan penginjilan dan pemuridannya, serta penting pengaruhnya. Tetapi pada umumnya, pelayanan mahasiswa Kristen kurang memiliki hubungan yang harmonis dengan gereja. Kegiatan pelayanan mahasiswa Kristen ini mempunyai banyak kemiripan dengan gereja mula-mula yang bertumbuh secara luar biasa pada Kisah Para Rasul. ${ }^{11}$ Dengan adanya pemikiran seperti di atas, sepertinya diperlukan pengenalan yang benar dan baik mengenai pertumbuhan gereja mula-mula yang luar biasa itu dan kesamaannya dengan pelayanan yang dilakukan oleh mahasiswa. Jikalau pelayanan mahasiswa Kristen adalah kepanjangan tangan gereja dalam pertumbuhannya, maka gereja adalah pendukung mahasiswa dalam pelayanannya.

\section{F. Kesimpulan}

Berdasarkan hal diatas penulis dapat menyimpulkan bahwa pentingnya mahasiswa dalam mengambil bagian dalam pelayanan di gereja. Pemberikan diri untuk melayani Tuhan adalah suatu kewajiban bagi kita percaya bahwa Yesus adalah Tuhan dan Juruselamat manusia. Seperti yang diarjakan kepada kita dalam Kitab Matius 28:19 “Karena itu pergilah, jadikanlah semua bangsa muridKu dan baptislah mereka dalam nama Bapa dan Anak dan Roh Kudus, dan ajarlah mereka melakukan segala sesuatu yang telah Kuperintahkan kepadamu. Dan ketahuliah, Aku menyertai kamu senantiasa sampai kepada akhir zaman".

\footnotetext{
${ }^{9}$ Doug Murren dan Mike Meeks dalam Buletin Kepemimpinan, Vol. 35, Tahun IX . (2011), 37

${ }^{10}$ Stefanus Maria Sumardiyo Adipranoto Pr, "Prinsip-prinsip Pemuridan" (Badan Pelayanan Nasional: 2006), 17

${ }^{11}$ Ch. Christanto. "Hubungan yang serasi antara Gereja dan Organisasi Para-Gereja”dalam pertumbuhan Pertumbuhan Gereja (Yogyakarta: Andi, 1994)135-136; bdk, M. Griffiths, Gereja dan Panggilannya Dewasa Ini (trans. O. S. Situmorang; Jakarta: Gunung Mulia, 1993) 189
} 